\title{
The Effect of Metal Materials on Heat Shock Protein 70B' Gene Expression
}

\author{
Junko Okuda-Shimazaki $^{1}$, Akiko Yamamoto ${ }^{2}$, Daisuke Kuroda ${ }^{3}$, Takao Hanawa ${ }^{4}$ and \\ Akiyoshi Taniguchi ${ }^{*}, 1$
}

\author{
${ }^{1}$ Cell-Sensing Group, Biomaterials Center, National Institute for Materials Science, 1-1 Namiki, Tsukuba, Ibaraki \\ 305-0044, Japan \\ ${ }^{2}$ Biometal Group, Biomaterials Center, National Institute for Materials Science, 1-1 Namiki, Tsukuba, Ibaraki \\ 305-0044, Japan \\ ${ }^{3}$ Department of Materials Science and Engineering, Suzuka National College of Technology, Shiroko, Suzuka, Mie \\ 510-0294, Japan \\ ${ }^{4}$ Institute of Biomaterials and Bioengineering, Tokyo Medical and Dental University, 2-3-10 Kanda-surugadai, \\ Chiyoda-ku, Tokyo 164-0011, Japan
}

\begin{abstract}
To avoid the toxic effect of released nickel ions and compounds from conventional stainless steels, nickel-free austenitic stainless steels have been developed. We previously established a new manufacturing process to produce nickel-free austenitic stainless steel that involves nitrogen adsorption treatment. Although the cytocompatibility of nickelfree austenitic stainless steel produced using this method has been evaluated using two viability assay, molecular level analysis, such as gene expression analysis, has not been previously performed. In the present study, the cytotoxicity of our nickel-free austenitic stainless steel, as well as of commercially available metal materials, was evaluated by analysis of heat shock protein 70B' (HSP70B') gene expression as a stress response marker. Furthermore, to investigate the effect of metal materials on cytotoxicity, HSP70B' gene expression was quantified using human osteoblast-like SaOS-2 cells, human monocyte THP-1 cells and the mouse macrophage cell line J774A.1. We found no significant differences in HSP70B' expression among the various metal materials, including the nickel-free austenitic stainless steel, indicating that the nickel-free austenitic stainless steel produced using our nitrogen adsorption method has the same cytocompatibility as commercially available metal materials.
\end{abstract}

\section{INTRODUCTION}

In order to avoid the toxic effect of released nickel ions and compounds from conventional stainless steels, nickelfree austenitic stainless steels were developed [1-4]. Generally, nickel-free austenitic stainless steels are difficult to work into fine foils and wires. To overcome this, we developed a new manufacturing process to produce nickel-free austenitic stainless steel by nitrogen adsorption treatment [5]. The cytocompatibility of nickel-free austenitic stainless steel produced using this nitrogen adsorption treatment has been evaluated by two different cytotoxicity tests, which indicated that this nickel-free austenitic stainless steel has higher cell growth and cytocompatibility than other nickel-free austenitic stainless steels [6]. However, a molecular level analysis, such as gene expression analysis, has never been performed.

The induction of heat shock protein (HSP) genes is a potential marker of general cytotoxicity, due to the fact that the expression of HSP genes can be substantially induced by a wide range of stimuli $[7,8]$. The most prominent inducible HSP is the 7,000 $\mathrm{kDa}$ protein, HSP70, and the expression of HSP70 mRNA is a valuable tool for estimation of biomaterial cytotoxicity [9-14]. In humans, at least eleven HSP70 genes have been previously identified [15]. HSP70B' was

*Address correspondence to this author at the Cell-Sensing Group, Biomaterials Center, National Institute for Materials Science, 1-1 Namiki, Tsukuba, Ibaraki 305-0044, Japan; Phone: +81-29-860-4505; Fax: +81-29-860-4714; E-mail: TANIGUCHI.Akiyoshi@nims.go.jp cloned by Leung et al. [16] as a novel HSP70 gene, and studies have suggested that the mRNA expression of this gene is greatly induced by cellular stresses and that its basal mRNA expression level is lower than that of other HSP70 genes $[17,18]$. Thus, HSP70B' may provide advantages in highsensitivity detection of cytotoxicity compared to HSP70.

In the present study, the cytotoxicity of nickel-free austenitic stainless steel produced by nitrogen adsorption treatment was evaluated by analysis of HSP70B' gene expression as a stress response marker.

\section{MATERIALS AND METHODS}

\section{Materials}

Nickel-free stainless steel Fe-24Cr-2Mo-1N, $18 \mathrm{Cr}-12 \mathrm{Ni}-$ 2Mo-0.02C, SUS316L, cpTi (JIS-2), titanium alloy Ti-6Al$4 \mathrm{~V}$ and Co-Cr-Mo alloy (ASTM F75-92) discs (diameter: 25 $\mathrm{mm}$, thickness: $2 \mathrm{~mm}$ ) were prepared by metallographically polished. The prepared disc surfaces were then ultrasonically cleaned with acetone (three $\mathrm{x} 1 \mathrm{~min}$ washes). Prior to seeding for culture, all discs were ultrasonically cleaned in $70 \%$ ethanol (20 $\mathrm{min})$, dried, and exposed to ultraviolet light for 3 min on each side.

\section{Cells and Cell Culture}

Human osteoblast-like SaOS-2 cells, derived from an osteosarcoma (American Type Culture Collection ATCC HTB 85) were routinely grown in McCoy's 5A medium supplemented with $10 \%$ fetal bovine serum (FBS) and $2 \mathrm{mM}$ 
glutamine. Human monocyte THP-1 cells, derived from peripheral blood (ATCC TIB 202) were routinely grown in RPMI1640 medium supplemented with 10\% FBS and $2 \mathrm{mM}$ glutamine containing $0.05 \mathrm{mM}$ 2-mercaptoethanol. Before seeding on the metal samples, THP-1 cells were differentiated with $50 \mathrm{nM} \mathrm{12-myristate} \mathrm{13-acetate} \mathrm{(PMA)} \mathrm{for} 72 \mathrm{~h}$. The differentiated THP-1 cells were adherent to the tissue culture polystyrene. Mouse macrophage cell line J774A.1 (ATCC TIB 67) was cultured in Dulbecco's Modified Eagle's Medium (DMEM) supplemented with 10\% FBS. Each cell was maintained in a fully humidified atmosphere consisting of $95 \%$ air $/ 5 \% \mathrm{CO}_{2}$ at $37^{\circ} \mathrm{C}$, and passaged every third or forth day. For analysis, SaOS-2 cells, THP-1 and J774A.1 cells were seeded onto each disc in 6-well plates at a density of $2 \times 10^{5}$ cells/well, $6 \times 10^{5}$ cells/well and $1 \times 10^{6}$ cells/well respectively, as well as onto tissue culture polystyrene without discs as the negative control. Cells were processed for RNA extraction as indicated below.

\section{mRNA Isolation, cDNA Synthesis and Real Time PCR}

Each cell line was cultured on the various metals for 24 h. To quantitatively assess the cellular expression level of HSP70B', total RNA was isolated from each cell using ISOGEN reagent (Nippongene, Japan) according to the manufacturer's instructions. Duplicate or triplicate samples were combined to ensure sufficient amounts of RNA. Total RNA was reversibly transcribed with a random hexamer primer using the SuperScript III First-Strand Synthesis System for RT-PCR (Invitrogen Life Technologies, USA) according to the manufacturer's instructions. Real time PCR was performed using the ABI PRISM ${ }^{\circledR} 7000$ sequence detection system (Applied Biosystems, USA). A $1 \mu$ aliquot of cDNA was mixed with $10 \mu \mathrm{l}$ of $2 \mathrm{x}$ Master Mix from the qPCRTM Mastermix Plus for SYBR ${ }^{\circledR}$ Green I QuickGoldStar kit (Eurogentec) and $1 \mu l$ of specific primer for human HSP70B' or human GAPDH. The primers for amplification of HSP70B' or GAPDH were 5'-CCGGCCCCATCATTGA G-3' and 5'-CCCATAGCATAGCCCTGACAGT-3' or 5'CCCCCACCACACTGAATCTC-3' and 5'-GCCCCTCCCC TCTTCAAG-3', respectively. The PCR procedure was as previously described [19-22]. The results from four independent tests were evaluated using the Dunnet type multiple comparison test.

\section{RESULTS AND DISCUSSION}

In order to investigate the effect of various metal materials on cytotoxicity at the gene expression level, HSP70B' gene expression was quantified using human osteoblast-like SaOS-2 cells, human monocyte THP-1 cells and a mouse macrophage cell line J774A.1.

Human osteoblast-like SaOS-2 cells were seeded on our nickel-free stainless Fe-24Cr-2Mo-1N and the commercially available metal materials SUS316L, cpTi, Titanium alloy Ti6Al-4V and Co-Cr-Mo alloy. No differences were observed in the initial adherent number among the metal materials (this term includes our nickel-free stainless $\mathrm{Fe}-24 \mathrm{Cr}-2 \mathrm{Mo}-$ $1 \mathrm{~N}$ unless otherwise noted) (data not shown). Analysis of cell proliferation also revealed no differences among the metal materials (data not shown). In addition, the morphology of seeded SaOS-2 cells, as determined by differential interference contrast microscopy, did not differ among the metal materials (Fig. 1).
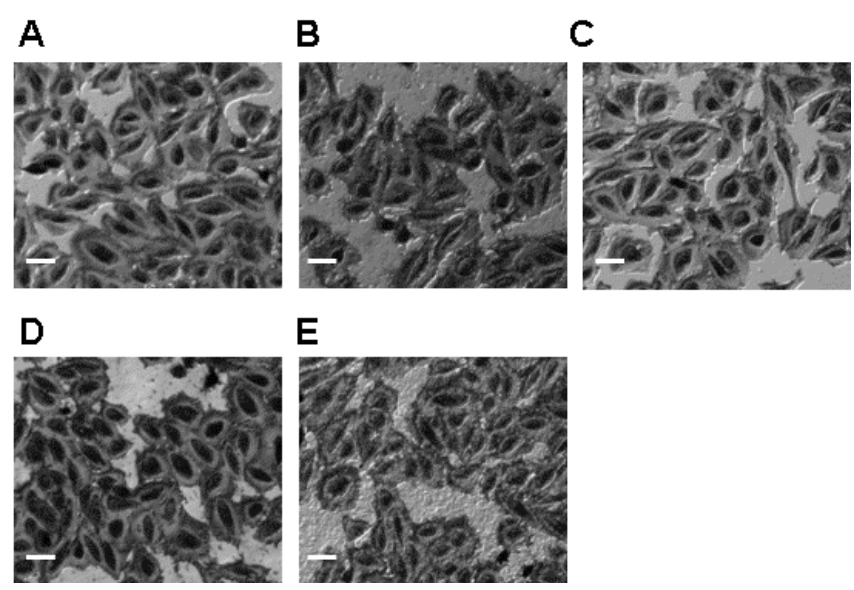

Fig. (1). Differential interference contrast microscopy pictures of SaOS-2 cells seeded on Fe-24Cr-2Mo-1N (A), SUS316L (B), CoCr-Mo (C), c.p.Ti (D) and Ti-6Al-4V (E). Bar $=50 \mu \mathrm{m}$.

To investigate the effect of the metal materials on cytotoxicity, HSP70B' gene expression was quantified by realtime PCR after 24 hour exposure to the metal materials. No significant increase in HSP70B' expression by the cells was noted among any of the various metal materials or on tissue culture polystyrene alone (negative control) whereas $1 \mathrm{mM}$ of $\mathrm{NiCl}_{2}$ induced $\mathrm{HSP} 70 \mathrm{~B}$ ' mRNA expression in SaOS-2 (Fig. 2).

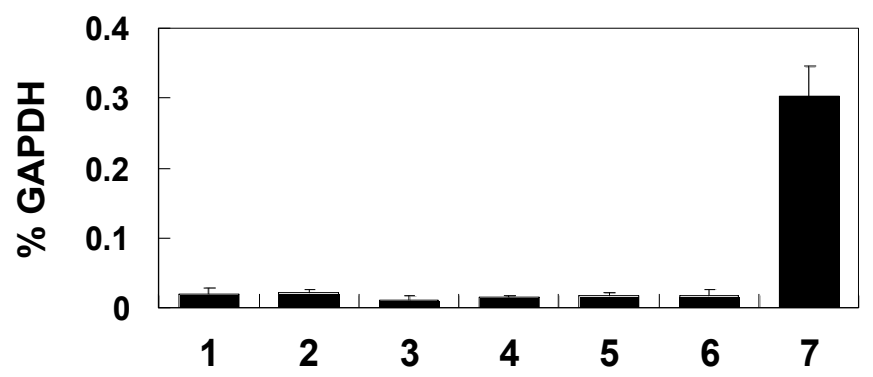

Fig. (2). HSP70B' mRNA levels of SaOS-2 cells seeded on Fe24Cr-2Mo-1N (1), SUS316L (2), Co-Cr-Mo (3) c.p.Ti (4), Ti-6Al$4 \mathrm{~V}$ (5), tissue culture polystyrene (TCPS) (6, as a negative control) and TCPS $+1 \mathrm{mM} \mathrm{NiCl}_{2}$ (7, as a positive control). The levels of HSP70B' mRNA were determined by quantitative real-time PCR and normalized against GAPDH. Results are representative of four experiments. Error bars indicate the standard deviation of mean changes. ${ }^{*} \mathrm{p}<0.01$ versus TCPS.

The seeding experiments were also reproduced with the mouse macrophages cell line J774A.1 and human monocyte THP-1 cells. Similar to SaOS-2 cells, the morphology of seeded J774A.1 and THP- 1 cells, as determined by differential interference contrast microscopy, did not differ among the metal materials or tissue culture polystyrene alone (Fig. 3 for J774A.1 cells and Fig. 5 for THP-1 cells).

On the other hand, a significant increase in HSP70B' expression by SaOS-2 and J774A.1 cells (Fig. 4), but not THP-1 cells (Fig. 6), was observed for all the metal materials and tissue culture polystyrene alone. Thus, these metal materials show little cytotoxicity to J774A.1 cells suggesting that metal materials have different effects on various cell lines.

In a previous study using two different cytotoxicity tests we found that nickel-free austenitic stainless steel produced 
by nitrogen adsorption treatment has higher cell growth and cytocompatibility than other nickel-free austenitic stainless steel [6]. In the present study, we found no significant difference in HSP70B' expression among various metal materials, including our nickel-free austenitic stainless steel, indicating that nickel-free austenitic stainless steel produced by nitrogen adsorption treatment has the same cytocompatibility as other commercially available metal materials.

A

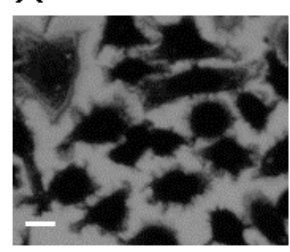

D

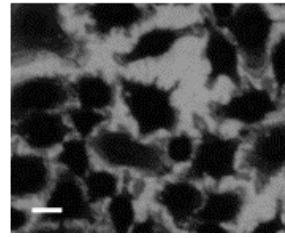

E

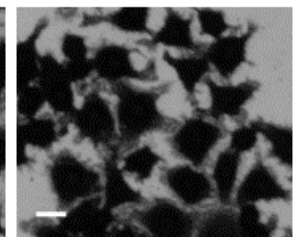

E

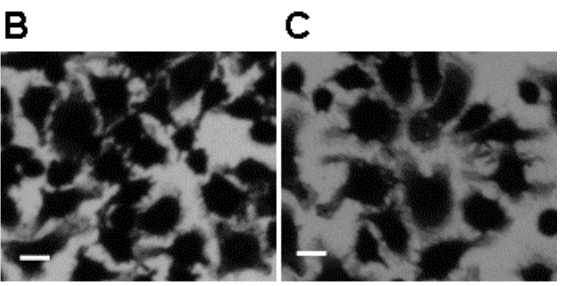

C

Fig. (3). Differential interference contrast microscopy pictures of J774A cells seeded on Fe-24Cr-2Mo-1N (A), SUS316L (B), Co-CrMo (C), c.p.Ti (D) and Ti-6Al-4V (E). Bar $=10 \mu \mathrm{m}$.

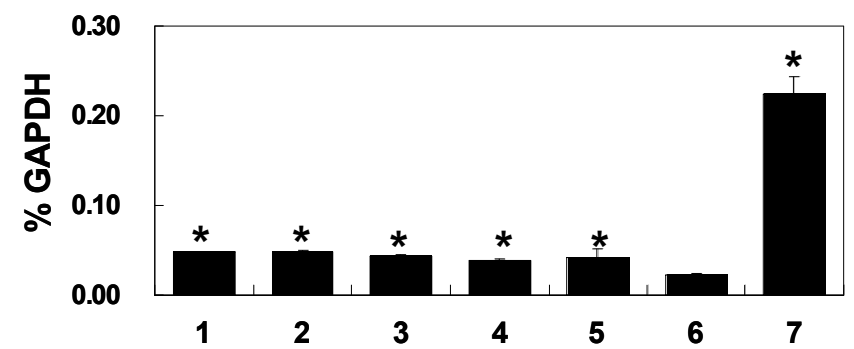

Fig. (4). HSP70B' mRNA levels of J774A cells seeded on Fe-24Cr2Mo-1N (1), SUS316L (2), Co-Cr-Mo (3) c.p.Ti (4), Ti-6Al-4V (5), TCPS (6, as a negative control) and TCPS $+1 \mathrm{mM} \mathrm{NiCl}_{2}$ (7, as a positive control). The levels of HSP70B' mRNA were determined by quantitative real-time PCR and normalized against GAPDH. Results are representative of four experiments. Error bars indicate the standard deviation of mean changes. ${ }^{*} \mathrm{p}<0.01$ versus TCPS.

A

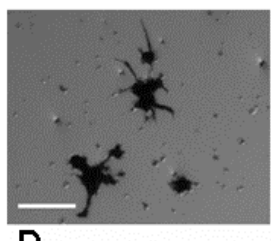

D

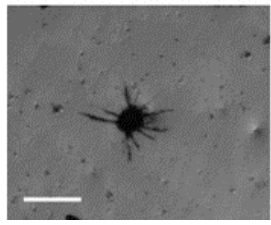

B

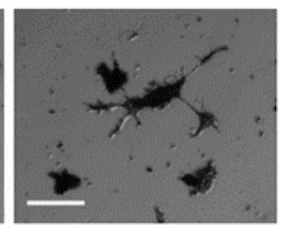

E

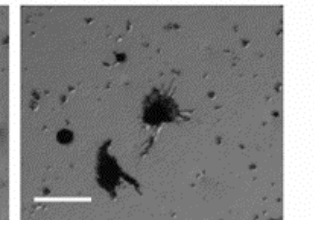

C

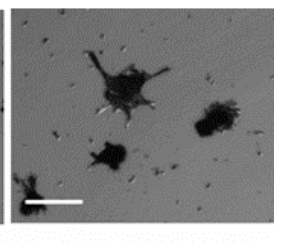

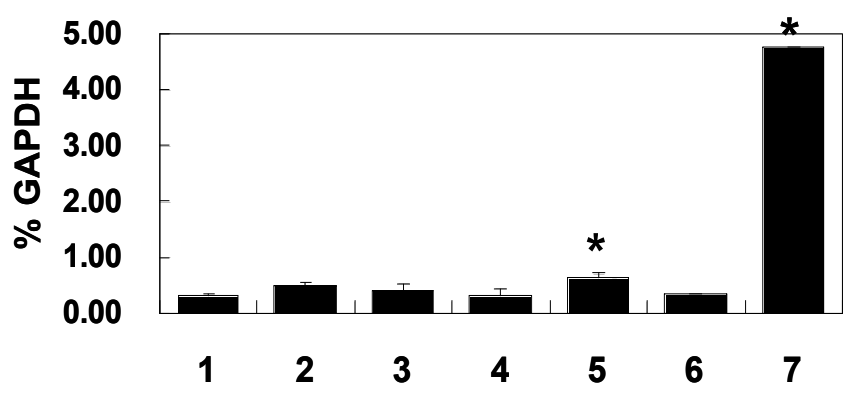

Fig. (6). HSP70B' mRNA levels of THP-1 cells seeded on Fe24Cr-2Mo-1N (1), SUS316L (2), Co-Cr-Mo (3) c.p.Ti (4), Ti-6Al$4 \mathrm{~V}(5)$, TCPS (6, as a negative control) and TCPS $+1 \mathrm{mM} \mathrm{NiCl}_{2}$ (7, as a positive control). The levels of HSP70B' mRNA were determined by quantitative real-time PCR and normalized against GAPDH. Results are representative of four experiments. Error bars indicate the standard deviation of mean changes. ${ }^{*} p<0.01$ versus TCPS.

\section{REFERENCES}

[1] Menzel J, Kirschner W, Stein G. High nitrogen containing Ni-free austenitic steels for medical applications. ISIJ Int 1996; 36: 893900.

[2] Uggowitzer PJ, Magdowski R, Speidel MO. Nickel free high nitrogen austenitic steels. ISIJ Int 1996; 36: 901-8.

[3] Gebeau RC, Brown RS. Biomedical implant alloy. Adv Mater Processes 2001; 159: 46-8.

[4] Katada Y, Sagara M, Kobayashi Y, Kodama T. Fabrication of high strength high nitrogen stainless steel with excellent corrosion resistance and its mechanical properties. Mater Manuf Processes 2004; 19: 19-22.

[5] Kuroda D, Hanawa T, Hibaru T, Kuroda S, Kobayashi M, Kobayashi T. New manufacturing process of nickel-free austenitic stainless steel with nitrogen absorption treatment. Mater Trans 2003; 44: 414-20.

[6] Yamamoto A, Kohyama Y, Kuroda D, Hanawa T. Cytocompatibility evaluation of $\mathrm{Ni}$-free stainless steel manufactured by nitrogen adsorption treatment. Mater Sci Eng C 2004; 24: 737-43.

[7] Kiang JG, Tsokos GC. Heat shock protein $70 \mathrm{kDa}$ : Molecular biology, biochemistry, and physiology. Pharmacol Ther 1998; 80: 183201.

[8] Schlesinger MJ. Heat-shock proteins. J Biol Chem 1990; 265: 12111-4.

[9] Hashimoto Y, Ueda A, Nakamura M. Evidence that HSP70 gene expression may be useful for assessing the cytocompatibility of dental biomaterials. Dent Mater J 2004; 23: 184-9.

[10] Higashiyama S, Noda M, Kawase M, Yagi K. Mixed-ligand modification of polyamidoamine dendrimers to develop an effective scaffold for maintenance of hepatocyte spheroids. J Biomed Mater Res 2003; 64A: 475-82.

[11] Kato S, Akagi T, Kishida A, Sugimura K, Akashi M. Evaluation of biological responses to polymeric biomaterials by RT-PCR analysis.2. Study of HSP 70 mRNA expression. J Biomater Sci Polym Ed 1997; 8: 809-14.

[12] Serizawa T, Yamaguchi M, Kishida A, Akashi M. Alternating gene expression in fibroblasts adhering to multilayers of chitosan and dextran sulfate. J Biomed Mater Res 2003; 67A: 1060-3.

[13] Weber N, Caliebe J, Ziemer G, Wendel HP. Material-dependent levels of heat-shock protein 70 (hsp70) in human plasma following contact of blood with artificial surfaces. J Biomater Sci Polym Ed 2003; 14: 747-60.

[14] Weber N, Wendel HP, Ziemer G. Gene monitoring of surfaceactivated monocytes in circulating whole blood using duplex RTPCR. J Biomed Mater Res 2001; 56: 1-8.

[15] Tavaria M, Gabriele T, Kola I, Anderson RL. A hitchhiker's guide to the human Hsp70 family. Cell Stress Chaperones 1996; 1: 23-8.

[16] Leung TKC, Rajendran MY, Monfries C, Hall C, Lim L. The human heat-shock protein family - expression of a novel heatinducible Hsp70 (Hsp70B') and isolation of its Cdna and genomic DNA. Biochem J 1990; 267: 125-32.

Fig. (5). Differential interference contrast microscopy pictures of THP-1 cells seeded on Fe-24Cr-2Mo-1N (A), SUS316L (B), CoCr-Mo (C), c.p.Ti (D) and Ti-6Al-4V (E). Bar $=10 \mu \mathrm{m}$. 
[17] Parsian AJ, Sheren JE, Tao TY, et al. The human Hsp70B gene at the HSPA7 locus of chromosome 1 is transcribed but nonfunctional. Biochim Biophys Acta 2000; 1494: 201-5.

[18] Wada KI, Taniguchi A, Xu LM, Okano T. Rapid and highly sensitive detection of cadmium chloride induced cytotoxicity using the HSP70B ' promoter in live cells. Biotechnol Bioeng 2005; 92: 4105.

[19] Ishibashi Y, Inouye Y, Okano T, Taniguchi A. Regulation of sialylLewis $\mathrm{x}$ epitope expression by TNF-alpha and EGF in an airway carcinoma cell line. Glycoconjugate J 2005; 22: 53-62.
[20] Kurosawa Y, Taniguchi A, Okano T. Novel method to examine hepatocyte-specific gene expression in a functional coculture system. Tissue Eng 2005; 11: 1650-7.

[21] Taguchi T, Xu LM, Kobayashi H, Taniguchi A, Kataoka K, Tanaka J. Encapsulation of chondrocytes in injectable alkali-treated collagen gels prepared using poly(ethylene glycol)-based 4-armed star polymer. Biomaterials 2005; 26: 1247-52.

[22] Xu LM, Harada H, Yokohama-Tamaki T, Matsumoto S, Tanaka J, Taniguchi A. Reuptake of extracellular amelogenin by dental epithelial cells results in increased levels of amelogenin mRNA through enhanced mRNA stabilization. J Biol Chem 2006; 281: 2257-62. 